\title{
The social thought of the Orthodox Church reflected in the documents of the Holy Pan-Orthodox Council of Crete (2016)
}

\begin{tabular}{|c|c|}
\hline $\begin{array}{l}\text { Authors: } \\
\text { luliu-Marius N }\end{array}$ & lorariu $^{1,2}$ \\
\hline $\begin{array}{l}\text { Affiliations: } \\
{ }^{1} \text { Faculty of Ort } \\
\text { Theology, 'Bab } \\
\text { University, Clu } \\
\text { Romania }\end{array}$ & $\begin{array}{l}\text { hodox } \\
\text { j-Napoca, }\end{array}$ \\
\hline $\begin{array}{l}{ }^{2} \text { Department } \\
\text { and Historical } \\
\text { Faculty of The } \\
\text { Religion, Univ } \\
\text { of Pretoria, Pr } \\
\text { South Africa }\end{array}$ & $\begin{array}{l}\text { f Systematic } \\
\text { Theology, } \\
\text { ology and } \\
\text { ersity } \\
\text { etoria, }\end{array}$ \\
\hline $\begin{array}{l}\text { Research Proj } \\
\text { Project Leade } \\
\text { Project numb }\end{array}$ & $\begin{array}{l}\text { ect Registration } \\
\text { r: T. van Wyk (D) } \\
\text { er: } 22153145\end{array}$ \\
\hline $\begin{array}{l}\text { Project Descri } \\
\text { Rev. Iuliu-Mari } \\
\text { participating in } \\
\text { project, 'Politic } \\
\text { directed by Dr } \\
\text { Department of } \\
\text { Historical Theo } \\
\text { of Theology an } \\
\text { University of P }\end{array}$ & $\begin{array}{l}\text { ption: } \\
\text { us is } \\
\text { the research } \\
\text { cal Theology', } \\
\text { Tanya van Wyk, } \\
\text { f Systematic and } \\
\text { logy, Faculty } \\
\text { id Religion, } \\
\text { retoria. }\end{array}$ \\
\hline $\begin{array}{l}\text { Correspondin } \\
\text { luliu-Marius N } \\
\text { maxim@radio }\end{array}$ & $\begin{array}{l}\text { g author: } \\
\text { lorariu, } \\
\text { renasterea.ro }\end{array}$ \\
\hline $\begin{array}{l}\text { Dates: } \\
\text { Received: } 21 \\
\text { Accepted: } 15 \\
\text { Published: } 29\end{array}$ & $\begin{array}{l}\text { Mar. } 2019 \\
\text { May } 2019 \\
\text { Nov. } 2019\end{array}$ \\
\hline $\begin{array}{l}\text { How to cite th } \\
\text { Morariu, I-M., } \\
\text { social thought } \\
\text { Orthodox Chu } \\
\text { in the docume } \\
\text { Pan-Orthodox } \\
\text { Crete (2016)', } \\
\text { Studies/Theolc } \\
75(4) \text {, a5471. } \\
10.4102 / \text { hts.v }\end{array}$ & $\begin{array}{l}\text { is article: } \\
2019, \text { 'The } \\
\text { of the } \\
\text { rch reflected } \\
\text { nts of the Holy } \\
\text { Council of } \\
\text { HTS Teologiese } \\
\text { gical Studies } \\
\text { https://doi.org/ } \\
75 \text { i4.5471 }\end{array}$ \\
\hline Read online: & \\
\hline 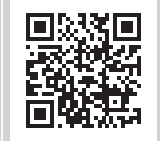 & $\begin{array}{l}\text { Scan this QR } \\
\text { code with your } \\
\text { smart phone or } \\
\text { mobile device } \\
\text { to read online. }\end{array}$ \\
\hline
\end{tabular}

An important moment in the history of the Orthodox Church is despite the withdrawal of local churches like the Bulgarian, Russian, Georgian and Alexandrian ones and the fear of Serbian Church to take part in it, the Pan-Orthodox Council of Crete remains an important meeting that influenced the history of Orthodoxy and shifted its conception to the world. The relevance of some of the topics discussed there explains why it can be found inside the important theological journals from the entire world chronicles of the event and articles dedicated to some of the topics investigated. Noticing this fact, we have tried to see the way the social thinking of the Orthodox Church is reflected in the documents released by the participants and its encyclical letter. Because of the fact that, until today, only the Russian Orthodox Church has a document that defines in an articulate way its social thinking and this one was published in 2002, when many challenges were not present in society, the ideas presented there are not only important for their relevance and actuality (because there are approached topics like fundamentalism, terrorism, nuclear weapons, family crisis, persecution of Christians of migration crisis), but also for the fact that they became the official document that articulates the landmarks of social thinking of the Eastern Orthodox Church, seen as a federation of local churches that are in Eucharistic and doctrinaire communion. Therefore, we have tried to see how the bishops presented to the Pan-Orthodox meeting, the way they understood and approached these topics and what represented the motivations of their conclusions.

Keywords: Migrant crisis; Fundamentalism; Nuclear weapons; Call for peace; Family crisis; Fasting.

\section{Introduction}

In the history of the Orthodox Church, the Council of Crete remains for sure an important moment (Makrides 2017:7). Rooted in the call of Patriarch Meletios Metaxakis from the Pan-Orthodox Congress from Constantinople from 1923 (Ioniță 2013:9), the event will be carefully prepared during the pre-conciliary meetings and by the documents drafted carefully (Viscuso 2016:5). Still, shortly before the event, because of the pressure of fundamentalist Orthodox people and also for reasons of Church politics, Russian, ${ }^{1}$ Georgian, Bulgarian and Alexandrian Churches withdrew and the Serbian one was close to doing it too (Heller 2017:289-293), a fact that determined the Christian world to be suspicious of the relationship between the role of this meeting and the real search for unity of the Orthodox Churches. ${ }^{2}$

Despite all the problems that appeared, the event has been observed, commented and debated both in the Orthodox area (Getcha 2017:274-287; Ioja 2016:7-8; Jovic 2017:103-114; Morariu 2015:247-254, 2018:1-5; Perşa 2017:131-157) and other Christian ones (Bouteneff 2016;10-12; D'Aloisio 2016:3-10; Farell 2017:87-98; Heller 2017:288-300; Heneghan 2016:12-13; Kattan 2016:11-15; Metso 2017:450-464; Thole 2017:27-38; Voulgaraki-Pissina 2017:136-150). Authors with Catholic or Protestant backgrounds were interested in the investigation of the official documents released by the meeting and tried to understand the way the decisions taken there can change the life of the Church. They have also tried to compare its approaches with documents

1.Which, in fact, has been constant in leaving the Pan-Orthodox meetings before their end because even the meeting from 1923 ended without their participation until its end (Viscuso 2016:18).

2.Nowadays the Ukrainian situation will surely intensify this debate, as can be seen from theological publications. See, for example, Editorial board (2018:420-434; 2018:329-281); Rozanskij and Zacharova (2019:18-19).

Copyright: (C) 2019. The Authors. Licensee: AOSIS. This work is licensed under the Creative Commons Attribution License. Note: HTS 75th Anniversary Maake Masango Dedication. 
of movements like the ecumenical one (Bordeianu 2017:518539). Despite this interest, there still can be found topics that were not investigated and are important not only for the Orthodox area, but also for the ecumenical one. One of them can be considered the social thinking of the Orthodox Church

Until the Council of Crete, there was only one Orthodox autocephalous Church that issued a document on this topic, namely the Russian one (Ică \& Marani 2002; Preda 2010:151-160). Drafted in 2000 and updated 2 years later (Morariu 2015:37), it represents a synthesis of the social thinking of the Orthodox Church approved by the Russian Holy Council. In the other Orthodox Churches, there are books and voices of representative authors that are used to answer a question that arises but not an official document. Therefore, it was expected for such a meeting to provide an articulated thought and a document intended to be normative at least for all the participating churches. If we take into account the fact that because of the context many doctrinaire aspects were not very much emphasised, we can say that it should be one of the most important tasks for the participants. Despite the relevance of the problem, there is not a document dedicated exclusively to the social problems and the way the Orthodox Church sees them, but only a few references to some of the most important problems.

Noticing this aspect and the relevance of social thought of the Church in a society like the contemporary one, we have tried to see how this topic is reflected in the documents of the Council of Crete. Encyclical (Constantinople 2016:291-304) and the six documents posted on the official site of the document (viewed 12 March 2019, from https://www. holycouncil.org/official-documents) will be our sources together with the articles and books dedicated to the event. Because of the fact that for many of the readers' topics like the 'Pan-Orthodox Council of Crete' are almost unknown, we will start by presenting the landmarks of its project and saying a few words about its purposes and outcomes, directing the readers who want to find more concerning the bibliography dedicated to this topic. Then, in a chapter dedicated to the way the social thought of the Orthodox Church is reflected in the documents of the Holy PanOrthodox Council of Crete (2016), we will investigate the main documents (like the one dedicated to the fasting process, the relationships of the Orthodox Church with the rest of the contemporary world or the one dedicated to the mission of the Church in the contemporary space), and will focus on the main topic, trying to offer to the reader a landscape of the way the aforementioned council contributed to the development and shifting of the social thinking of the Church and its way of acting.

\section{Holy Pan-Orthodox Council of Crete - Historical landmarks}

Before speaking about the way the social thinking of the Orthodox Church is reflected in the documents released by the participants of the event, we consider it important to present some aspects related with the history and the preparation of the event. As already mentioned, the idea of a Pan-Orthodox Council has been enounced for the first time by the Ecumenical Patriarch Meletios Metaxakis in the Congress of the Orthodox Churches held in Constantinople in 1923 (Ioniță 2013:9).

From that call to the event there was a long road. Therefore, the first pre-conciliar conference took place in Chambesy, Switzerland, between 21 and 28 November 1976 and was followed by another three, held in the same place from 03 to 12 September 1982, 20 October to 06 November 1986 and 06 to 12 June 2009 (Ioniță 2013:9-11). All these meetings were followed by some preparatory meetings.

The first took place from 29 September to 04 October 2014 in the same place, and 13 autocephalous churches were present (Ioniță 2016:24), the ones from Czech and Slovakian spaces being absent (Ioniță 2013:16).

During all these meetings, the main topics that were supposed to be debated were decided upon.

If one takes a look at them, at least two important aspects will be noticed: the first is the fact that although the bishops who participated never thought to draft a document dedicated especially to the social teaching of the Church, this aspect was highly debated. The second is that there were many changes in this aspect. For example, in the first meeting from 1976, the topics chosen were as follows:

1. the Orthodox diaspora

2. autocephaly and the proclamation procedure of it

3. autonomy and the proclamation procedure of it

4. the diptychs

5. the calendar problem

6. the impediments to marriage

7. the upgrade of Church positions regarding fasting

8. the relationships of the Orthodox Church with the rest of Christian world

9. Orthodoxy and the Ecumenical Movement

10. contribution of the local Orthodox Church in the realisation of Christian ideals of peace, brotherhood and love between people and the overcoming of racial discriminations. (Ioniță 2013:9-10, 2016:25-28)

In the future meetings, some of the documents were reformulated, others deleted because of the impossibility to achieve a consensus between the participants. Even in the first meeting, three were cancelled and there were only seven left. At the end, as it can be seen (viewed 12 March 2019, from https://www.holycouncil.org/official-documents), there are only six left, namely 'The Importance of Fasting and Its Observance Today', 'Relations of the Orthodox Church with the Rest of the Christian World', 'Autonomy and the Means by which it is Proclaimed', 'The Orthodox Diaspora', 'The Sacrament of Marriage and its Impediments' and 'The Mission of the Orthodox Church in Today's World' (Constantinople 2016:291-304). 
From the point of view of the topic that we investigate, the chapters dedicated to fasting, relationships of Orthodoxy with the rest of Christian world, marriage and mission of Church nowadays are linked with the social teaching of the Church. If we take a look to the first list, we will see that, in fact, the bishops and theologians who participated in the preliminary meetings decided not to delete the topics, but to subsume them into a larger topic that is linked with their main meaning. But what is important for our investigation is the fact that from six big chapters of the final document, four are linked with the investigated topic.

Of course, the aspects related with autonomy and autocephaly allowed Churches like the Russian and Alexandrian ones to decide not to participate in the Council, while financial problems were the reason to withdraw for the Bulgarian one and the increase of fundamentalists for Georgian ones.

But despite all the problems, delegates of the other Orthodox Churches who participated in the previous meetings (Morariu 2016b:78-85) met between 20 and 26 June 2016 in Crete island to take part in an event called by some of the participants 'the culmination of a century of preparation' (Getcha 2017:274; Meimaris 2013:12) that will bring the Orthodoxy in a new ecumenical era (Nissiotis 1985:326). Respecting the decisions taken by the previous meeting, they have also decided that:

It cannot be inserted into the debates of the Council the text that have not received the unanimous approval inside the Preconciliar Pan-Orthodox Conferences and by the Synaxis of the Primates of Autocephalous Orthodox Churches, with the exception of the final message of the Council whose' message must be prepared by a special committee one week before the call for the Council, with the approval of the Primates. (Ioniță 2013:88)

\section{The social thought of the Orthodox Church reflected in the documents of the Holy Pan-Orthodox Council of Crete (2016)}

After the presentation of the main aspects related with the history of Pan-Orthodox Council of Crete and the topics debated, we will try to see, using the Encyclical letter issued by the participants (Constantinople 2016:291-304; Redaction 2016a:305-311, 2016b:324-355) $)^{3}$ and the documents of the meeting, how the social thinking of the Church is reflected in its decisions. While in the first aforementioned document each aspect presented in the other ones is presented in a summarised way, in each one of the six documents there is a large vision on a specific topic developed.

When one reads our presentation, he could ask himself why the debate dedicated to fasting and its relevance (viewed 12 March 2019, from https://www.holycouncil.org/-/fasting post) can be considered important for the social thinking of the Church. It could be for sure important for a theological 3.Ail the documents were later published inside a volume in Brepols (see Mellon 2016).
(Jovic 2017:103-114) or canonical investigation (Perşa 2017:131-147) rather than for one made from this perspective. But if we consider it in the context of 'great contemporary humanitarian crisis' (Constantinople 2016:301) and link it with the relationship between Church and consumerism or resources and their management, we will see for sure that there are aspects of it that can be found there. For example, underlining the social dimension of fasting and presenting in the context of interaction between resources, self-control and theology, the authors of the document show that:

Everyone is called to strive, to the best of his or her abilities, to reach the lofty Orthodox standard, which is the goal of deification by grace. Indeed, while they should do all things that they were commanded, they should nonetheless never vaunt themselves, but confess that 'they are unprofitable servants and have only done that which was their duty to do' (Lk 17:10). According to the Orthodox understanding of the spiritual life, all people are obligated to maintain the good struggle of the fast; however, in a spirit of self-reproach and humble recognition of their condition, they must rely upon God's mercy for their shortcomings, inasmuch as the Orthodox spiritual life is unattainable without the spiritual struggle of the fast. (Viewed 12 March 2019, from https://www.holycouncil.org/-/fasting)

Speaking about the way the Church understands her role as a mother, they also underline the role of oikonomia and the fact that there are alternative ways of fasting, which can be directed both to the interior spiritual life and to the neighbour. Therefore, although they have theological motivations, the social dimension is not neglected either and it has also a place in the passage dedicated to this topic from the council debates.

Also, it must be mentioned that, like the message of Second Vatican Council for the Catholics, the one of Crete is not addressed only to the Orthodox Christians, but also to the entire world. ${ }^{4}$ Moreover, the principles of the Gospel are presented not in a confessional way, but in a holistic context and the mission of the Church is seen as composed by 'living for the others':

The Church lives not for herself. She offers herself for the whole of humanity in order to raise up and renew the world into new heavens and a new earth (cf. Rev 21.1). Hence, she gives Gospel witness and distributes the gifts of God in the world: His love, peace, justice, reconciliation, the power of the Resurrection and the expectation of eternal life. (Constantinople 2016:438)

Still, the richest aspects that define the social thinking of the Orthodox Church can be found in the documents dedicated to the presentation of the relationship of the Church with the contemporary world and the one linked with mission. Some of the ideas expressed there, like the one about technology and its role, can be found in the ideas expressed before by the Ecumenical Patriarch Bartholomew (Bartholomew 2014:316) or other Orthodox thinkers.

4.'Therefore, with one voice and one heart we address this message of "the hope that is in us" (cf. $1 \mathrm{Pt} 3.15$ ) not only to the sons and daughters of our most holy Church, but also to 
Linking experience of the Church with laws and canons (Perşa 2017:132), the participants of the meeting spoke about the crisis of the family and marriage, seen as a consequence of the misunderstood freedom:

The contemporary crisis in marriage and the family is a consequence of the crisis of freedom as responsibility, its decline into a self-centred self-realization, its identification with individual self-gratification, self-sufficiency and autonomy, and the loss of the sacramental character of the union between man and woman, resulting from forgetfulness of the sacrificial ethos of love. Contemporary society approaches marriage in a secular way with purely sociological and realistic criteria, regarding it as a simple form of relationship - one among many others - all of which are entitled to equal institutional validity. (Constantinople 2016:295-296)

The fact that they link this topic with the youth ${ }^{5}$ is also important like the approach to the problem. Speaking about marriage as a sacrament links it both with the perpetuation of the human race and with the functionality of the society. Therefore, they insist on the fact that contemporary education must take into consideration the communitarian structure and mission of man and teach human beings how to overcome individualism (Constantinople 2016:296).

In the document dedicated to the relationships between the Church and contemporary world, a main point is dedicated to the evolution of science. After greeting this aspect and noticing that this has a double meaning because of the fact of changes in human life making some of its aspects easier than before, the authors also underline the questions that this evolution raises today in the area of bioethics (Morariu 2016a:246-254), traditions, culture and identity. ${ }^{6}$ They will also speak about the fact that the evolution of science provides man with the possibility of evolution in their spiritual life and that, in normal conditions, they could be complementary (Toma et al. 2017:162). At the same time if it is misunderstood, as often happens during history, science can lead human beings in a direction that will make him lose his sense and soul. They say about this:

The consequences of evil include those imperfections and shortcomings prevailing today, including: secularism; violence; moral laxity; detrimental phenomena such as the use of addictive substances and other addictions especially in the lives of certain youth; racism; the arms race and wars, as well as the resulting social catastrophes; the oppression of certain social groups, religious communities, and entire peoples; social inequality; the restriction of human rights in the field of freedom of conscience - in particular religious freedom; the misinformation and manipulation of public opinion; economic misery; the disproportionate redistribution of vital resources or complete lack thereof; the hunger of millions of people; forced migration

5.And say about them that: 'The young people thus are not simply the "future"' of the Church, but also the active expression of her God-loving and human loving life in the present' (Constantinople 2016:296).

6.'Through the contemporary development of science and technology, our life is changing radically. And what brings about a change in the life of man demands discernm discernment on his part, since, apart from significant benefits, such as the facilitation of everyday life, the successful treatment of serious diseases and space exploration, we are also confronted with the negative consequences of scientific progress. The dangers are the manipulation of human freedom, the use of man as a simple means, the gradual loss of precious traditions, and threats to, or even the destruction' (Constantinople 2016:298). of populations and human trafficking; the refugee crisis; the destruction of the environment; and the unrestrained use of genetic biotechnology and biomedicine at the beginning, duration, and end of human life. These all create infinite anxiety for humanity today. (Viewed 13 March 2019, from https: / / www. holycouncil.org/-/mission-orthodox-church-todays-world)

The emphasis on the crises of economic misery, racism, relationship between freedom and conscience or human rights like the ecology influenced by the ideas of the Ecumenical Patriarch Bartholomew (Bartholomée 2015) is important and it shows that the Orthodox Church is really concerned by the evolution of today's world. At the same time, there is a sign of openness and a call to dialogue, both with other Christians and with state and authorities that may even shift the missiological dialogue and conception of this topic in the next years. In fact, this call is also visible in the next passages of the paragraph, where the participant bishops release a call to cooperate to the entire Christian world, ${ }^{7}$ having as a main principle the value of human persons (therefore referring to human dignity and underlining its relevance).

Speaking about the relationships between local churches and diaspora, the bishops also present the normal landmarks of the relationships between state and Church, using as landmark the aforementioned principle:

The local Orthodox Churches are today called to promote a new constructive synergy with the secular state and its rule of law within the new framework of international relations, in accordance with the biblical saying: 'Render to Caesar the things that are Caesar's and to God the things that are God's' (cf. Matt 22.21). This synergy must, however, preserve the specific identity of both Church and state and ensure their earnest cooperation in order to preserve man's unique dignity and the human rights which flow therefrom, and in order to assure social justice. (Constantinople 2016:300)

The keywords of this discourse are identity, human rights, human dignity and synergy. Therefore, the authors plead for cooperation and synergy, which is a testimony of the will for peace and welfare of the Church, but only under some specific conditions. Speaking about human dignity and the relevance of respecting it, they let it be understood the relevance of life, freedom of thought and religion, but understood in the key of responsibility.

Another important call that comes from the documents of the Council is the one for peace. The bishops express their consciousness of the fact that, during the latest years, fundamentalism has become an important problem for the society:

We are experiencing today an increase of violence in the name of God. The explosions of fundamentalism within religious communities threaten to create the view that fundamentalism belongs to the essence of the phenomenon of religion. The truth,

7. On this basis, it is essential to develop inter-Christian cooperation in every direction for the protection of human dignity and of course for the good of peace, so that the peace-keeping efforts of all Christians without exception may acquire greater weight and significance' (viewed 13 March 2019
org/-/mission-orthodox-church-todays-world). 
however, is that fundamentalism, as 'zeal not based on knowledge' (Rom 10.2), constitutes an expression of morbid religiosity. A true Christian, following the example of the crucified Lord, sacrifices himself and does not sacrifice others, and for this reason is the most stringent critic of fundamentalism of whatever provenance. (Constantinople 2016:301)

After condemning this bad behaviour that is often seen in other spaces like the Christian one, but in some situations can be seen also there (where usually fundamentalism does not lead to terrorism or crime, but brings schisms, hate and different forms of violence), they face the problem of persecuted Christians from the Middle East and release a call to local governments to protect local populations and to guarrantee the freedom stipulated in their constitutions:

The Orthodox Church is particularly concerned about the situation facing Christians, and other persecuted ethnic and religious minorities in the Middle East. In particular, she addresses an appeal to governments in that region to protect the Christian populations - Orthodox, Ancient Eastern and other Christians - who have survived in the cradle of Christianity. The indigenous Christian and other populations enjoy the inalienable right to remain in their countries as citizens with equal rights. (Constantinople 2016:302)

Similarities with documents like World Council of Churches's Together Towards Life (Keum 2013), Lumen Gentium or others from the Second Vatican Council can be found, where the call to dialogue is focused not only on moral problems and social ones related with human persons as individuals, but also on states and international policy. An example is the paragraphs dedicated to nuclear weapons ${ }^{8}$ where it is expressed the concern of the Orthodox Church regarding this aspect and a call to destroy them is addressed to the rulers of powerful countries that possess this kind of weapon.

Of course, what should not be neglected either is the contemporary crisis of migration which caused the bishops and the local churches that took part in the event to release also a call to receive and provide assistance to all the ones who, forced by the situation of their home country, seek refuge in other lands:

We appeal therefore first of all to those able to remove the causes for the creation of the refugee crisis to take the necessary positive decisions. We call on the civil authorities, the Orthodox faithful and the other citizens of the countries in which they have sought refuge and continue to seek refuge to accord them every possible assistance, even from out of their own insufficiency. (Constantinople 2016:302)

8.For example, it is said: 'The amassing not only of nuclear, chemical, and biological weapons, but of all kinds of weapons, poses very serious dangers inasmuch as they create a false sense of superiority and dominance over the rest of the world. Moreover, such weapons create an atmosphere of fear and mistrust, becoming the impetus for a new arms race. The Church of Christ, which understands war as impetus for a new arms race. The Church of Christ, which understands war as essentially the result of evil and sin in the world, supports all initiatives and efforts to prevent or avert it through dialogue and every other viable means. When war becomes inevitable, the Church continues to pray and care in a pastoral manner for her children who are involved in military confict for the sake of defending their life and freedom, while making every effort to bring about the swift restoration of peace
and freedom' (viewed 13 March 2019, from https://www.holycouncil.org/-/ mission-orthodox-church-todays-world).

\section{Conclusion}

Although it does not provide a systematic document that circumscribes the social thinking of the Orthodox Church from the entire world and neglects to investigate deeply aspects like bioethics, or does not mention topics like 'social media' that became very important during the last years, the Council of Crete provides, as we have tried to show, an overview of this topic through the documents released. Influenced most probably by the fact that the social document of the Russian Orthodox Church from 2002 (Ică \& Marani 2002) has already presented a coherent vision on problems like euthanasia or the relationship between Church and state, the participants in the Pan-Orthodox meeting only mention them, without dedicating a large space to their presentation and investigation (unfortunately, the limits of this research do not allow us to develop more this topic and to show how the Council focused on topics like bioethics, but we did it before in another research: Morariu 2016a:247-254). They will prefer to focus on current problems like the crisis of resources, the questions raised by the evolution of science and technology, crisis of migrants, terrorism and religious fundamentalism, and to address calls for love and peace to the entire world. Also, the fact that topics like family crises and fasting are approached not only from their theological point of view, but also from their value for the social life of the Church and of the world. The authority that issued the document calls for cooperation from all people, especially Christians, and shows the availability of local Orthodox Churches not only to dialogue, but also their concern for the evolution of the contemporary world.

The fact that the Council of Crete avoided not only ardent doctrinaire problems, but also some administrative ones that could anger the local churches who refused to take part at the event will most probably make its decisions be accepted in a short time by the entire Orthodoxy and the aspects of social thinking of the event normative for this confessional space. For sure, a future meeting of the primates of Eastern Orthodox Churches will have on its list topics like this ones and will not only focus on the way the contemporary world has changed and how its changes challenge the Church today, asking for new approaches and solutions, but will also present and highlight new problems and topics that will become relevant for the spiritual life and for the relationship between the contemporary world and the Church or about how the decisions dedicated to topics like autocephaly influenced situations like the Ukrainian one (this could be for sure a topic for a future research).

\section{Acknowledgement Competing interest}

The author declares that no competing interest exists.

\section{Author contributions}

I declare that I am the sole author of this research article. 


\section{Ethical consideration}

This article followed all ethical standards for carrying out research without direct contact with human or animal subjects.

\section{Funding}

This research received no specific grant from any funding agency in the public, commercial, or not-for-profit sectors.

\section{Data availability statement}

Data sharing is not applicable to this article as no new data were created or analysed in this study.

\section{Disclaimer}

The views and opinions expressed in this article are those of the authors and do not necessarily reflect the official policy or position of any affiliated agency of the authors.

\section{References}

Bartholomée, P.O., 2015, Et Dieu vit que cela était bon. La vision théologique de la création dans la tradition orthodoxe, Les Editions du Cerf, Paris.

Bartholomew, E.P., 2014, 'Address by his All-Holiness Ecumenical Patriarch Bartholomew at the Synaxis of the Primates of the Orthodox Churches', Greek Orthodox Theological Review 59(1-4), 313-325.

Bordeianu, R., 2017, 'Getting from conflict to communion: Ecclesiology at the Center of Recent Lutheran-Orthodox Dialogues and the 2016 Orthodox Council of Crete', Worship 91(1), 518-539.

Bouteneff, P., 2016, 'Great and Holy Council', Christian Century 133(20), 10-12.

Constantinople, B., 2016, 'Encyclical of the Holy and Great Council of the Orthodox Church, Crete 2016', Ecumenical Review 68(2-3), 291-304. https://doi.org/ 10.1111/erev.12228

D’Aloisio, C., 2016, 'En attendant les fruits du Concile du Crète', Le MessagerOrthodoxe 2(161), 3-10

Editorial board, 2018, 'Patriarchats de ConstantinopoleedteMoscou: Declarations surl'autocephalie en Ukraine', Istina 68(4), 420-434. https://doi.org/10.1016/ S0011-9164(18)30345-X

Editorial board a, 2018, 'Chronique des Eglises', Irenikon 91(2), 329-381.

Farell, B., 2017, 'Report on the activities of the pontifical council for promoting Christian unity during 2016', Catholica 71(2), 87-98.

Getcha of Telmessos, Job, 2017, 'The ecumenical significance of the Holy and Great Council of the Orthodox Church', The Ecumenical Review 69(2), 274-287. https:// doi.org/10.1111/erev.1228

Heller, D., 2017, 'The (Holy and Great) Council of the Orthodox churches: An ecumenical perspective', The Ecumenical Review 69(2), 288-300. https://doi. org/10.1111/erev.12289

Heneghan, T., 2016, 'Orthodox leaders hold historic council', Christian Century 133(15), 12-13.

Ică, I. Jr. \& Marani, G., 2002, Gândireasocială a Bisericii. Fundamente- documente analize- perspective, [Social taught of the Church. Fondements - documents analyses - perspectives], Deisis Press, Sibiu.

Ioja, C., 2016, 'The Holy and Great Synod - Sinodality and co-responsibility in the current world', Teologia 68(3), 7-8.
Ioniţă, V., 2013, Hotărârile întrunirilor panortodoxe din 1923 pânăîn 2009 - spre Sfântul si Marele Sinod al Bisericii Ortodoxe, [The decisions of pan-orthodox meetings from 1923 until 2009 - through the Saint and Great Council of Orthodox Church], Basilica Publishing House of Romanian Patriarchate, Bucharest.

Ioniţă, V., 2016, Sfântul şi MareleSinod al Bisericii Ortodoxe - documente pregătitoare [Holy and Great Council of Orthodox Church - preparatory documents], Basilica Publishing House of Romanian Patriarchate, Bucharest.

Jovic, R., 2017, 'The importance of fasting and its observance for tomorrow', Studia Universitatis Babes-Bolyai - Series Theologia Orthodoxa 1(62), 103-114. https:// doi.org/10.24193/subbto.2017.1.07

Kattan, A.E., 2016, 'Le concile de Crète: en espérantque nous apprenions', Le Messager Orthodoxe 2(161), 11-15.

Keum, J., 2013, Together towards life. Mission and Evangelism in Changing Landscapes With a practical guide, World Council of Churches Publications, Geneva.

Makrides, V.N., 2017, 'Le concile panorthodoxe de 2016. Quelques réflexions sur les défis aux quels le monde orthodoxe doit faire face', Istina 72(1), 5-26.

Meimaris, T.A., 2013, The Holy and Great Council of the Orthodox Church \& the ecumenical movement, Ant. Stamoulis Publications, Thesaloniki.

Melloni, A. (ed.), 2016, The Great Councils of the Orthodox Churches, Decisions and Svnodika, Vol. 3: Crete 2016, Brepols, Turnhout.

Metso, P., 2017, 'Ecclesial self-understanding and relationships of local churches in the documents of the Pan-Orthodox Council of Crete [Kirkollinen itseymmärrys ja paikalliskirkkojen yhteydet Kreetan yleisortodoksisen synodin asiakirjoissa]', Teologinen Aikakauskirja 12(5-7), 450-464.

Morariu, M., 2015, ,Fundamentele concepţiei sociale a Bisericii Ortodoxe Ruse reflectate în documentul sinodal din anul 2000 [The fondements of social conception of Russian Orthodox Church reflected in the conciliar document from 2000]', Tabor 9(4), 37-41.

Morariu, I.-M., 2016a, 'Bioethics in the discussions of the pan-Orthodox synod from Crete (2016)', Astra Salvensis 4(7), 247-254.

Morariu, I.-M., 2016b, 'The Romanian Delegations to the Holy Pan-Orthodox Synod of Crete (2016) and to the its preliminary assemblies and their importance for theological discussions', Teologia 69(4), 78-85.

Morariu, I. -M., 2018, 'Eastern Orthodox Churches and Ecumenism according to the Holy Pan-Orthodox Council of Crete (2016)', HTS Teologiese Studies/Theological Studies 74(4), a 4954, 1-5. https://doi.org/ 10.4102/hts.v74i4.4954.

Nissiotis, N., 1985, 'Towards a new ecumenical era', The Ecumenical Review 37(3), 326-335. https://doi.org/10.1111/j.1758-6623.1985.tb01323.

Perşa, R., 2017, 'A canonical analysis of the most controversial phrase of the Holy and Great Council: "The Orthodox Church accepts the historical name of othe non-Orthodox Christian churches and confessions that are not in communion with her"', Studia Universitatis Babes-Bolyai - Series Theologia Orthodoxa 1(62) 131-157. https://doi.org/10.24193/subbto.2017.1.09

Preda, R., 2010, Ortodoxia \& ortodoxiile. Studii social teologice [Orthodoxy and the orthodoxies. Social-theological studies], Eikon Press, Cluj-Napoca.

Redaction, 2016a, 'Relations of the Orthodox Church with the rest of the Christian world draft document of the Pan-Orthodox Council, Adopted by the 5th PanOrthodox Pre-Council Conference in Chambesy 10-17 October 2015', The Ecumenical Review 68(2-3), 305-311. https://doi.org/10.1111/erev.12229

Redaction, 2016b, 'The mission of the Orthodox church in today's world', Internationa Review of Mission 105(2403), 324-355. https://doi.org/10.1111/irom.12155

Rozanskij, V. \& Zacharova, C., 2019, 'Nasce la nuova Chiesa ucraina e l'Ortodossia si divide', Asia News 33(321) (2), 18-19.

Thole, R., 2017, 'Le Saint et grand Concile de l'Egliseorthodoxe (Crète, 2016) entre epreuve et promesse. Un écholutherien', Istina 62(1), 27-38.

Toma, V.A., Morariu, I.-M., Hădadea, C. \& Echim, D., 2017, 'Theology and Biology. Aneducational dimensions of the transdisciplinary approach regarding Genesis and biological evolution', in I. Albulescu, A.-D. Manea \& I.-M. Morariu (eds.) Education, religion, family in contemporary society - Proceedings of the conference, pp. 159-165, Lambert Academic Publishing, Saarbrucken.

Viscuso, P., 2016, Quest for reform of the Orthodox Church. The 1923 Pan-Orthodox Congress. AN Analysis and Translation of its Acts and decisions, Inte Orthodox Press, Berkeley, CA.

Voulgaraki-Pissina, E., 2017, 'Reading the document on mission of the Holy and Great Council from a missiological point of view', International Review of Mission 106(1), 136-150. https://doi.org/10.1111/irom.12172, viewed 12 March 2019, from https://www.holycouncil.org/official-documents. 